BISMA

(Bisnis dan Manajemen)
Volume 12, Issue 1, October 2019, 54-65

ISSN 2549-7790 (Online)

ISSN 1979-7192 (Print)

DOI: 10.26740/bisma.v12n1.p54-65

https://journal.unesa.ac.id/index.php/bisma/index

\title{
The impact of marketing approach changes to school'sselection decision
}

\author{
Afriyani $^{1}$, Ibnu Harris ${ }^{2 *}$, and Muhammad Adli Fata ${ }^{3}$ \\ ${ }^{1}$ Department of Management, Faculty of Business, UniversitasUniversal \\ Kompleks Maha Vihara Duta Maitreya, Kota Batam 29456, Indonesia \\ afriyani_chen@yahoo.com \\ ${ }^{2}$ Department of Management, Faculty of Business, UniversitasUniversal \\ Kompleks Maha Vihara Duta Maitreya, Kota Batam 29456, Indonesia \\ me@ibnuharris.my.id \\ ${ }^{3}$ School of Computer Sains, Universiti Sains Malaysia \\ Penang Island, Malaysia \\ adlifata@student.usm.my
}

\begin{abstract}
Maitreyawira Playgroup/Kindergarten School is one of the long-standing and reputable educational institutions in Batam. However, promotion strategy needs to be carried out to communicate educational services to the community to influence an individual's school selection decisions. In this study, there are four variables in the promotional mix element. This research is intended to determine the effectiveness of marketing which is influenced by changes in marketing functions. The data collection method in this study was carried out by distributing questionnaires to the parents whose children study in the Maitreyawira Playgroup/Kindergarten School in Batam and considered as the new service user who experiences the service. The data analysis was conducted into stages such as F-test, t-test, and multiple linear regression analysis. The results of this study indicate that WoM (word of mouth) influences Maitreyawira Playgroup/Kindergarten school selection decisions, while e-WoM (electronic word-of-mouth) does not influence the decision to choose Maitreyawira Playgroup/Kindergarten schools.
\end{abstract}

Keywords: e-WoM; school's selection decision; WoM.

Received: April16, 2019;Accepted: August 14, 2019; Published: October 17, 2019

*Corresponding author

Email:me@ibnuharris.my.id

How to cite this document:

Afriyani, Harris, I., \&Fata, M.A. (2019). The impact of marketing approach changes to school's selection decision. BISMA (Bisnis dan Manajemen), 12(October), 54-65. https://doi.org/10.26740/bisma.v12n1.p54-65 


\begin{abstract}
Abstrak
Kelompok Bermain/Taman Kanak-kanak Maitreyawira merupakan salah satu lembaga pendidikan yang telah lama berdiri dan memiliki reputasi yang baik di Batam. Meskipun demikian, strategi promosi perlu dilakukan untuk mengkomunikasikan layanan pendidikan kepada masyarakat dengan tujuan mempengaruhi individu dalam pengambilan keputusan pemilihan sekolah. Dalam penelitian ini terdapat 4 variabel bauran promosi. Penelitian ini dimaksudkan untuk mengetahui efektivitas pemasaran yang dipengaruhi oleh perubahan fungsi pemasaran. Metode pengumpulan data dalam penelitian ini dilakukan dengan membagikan kuisioner kepada orang tua yang anak-anaknya belajar di Kelompok Belajar/Taman Kanak-kanak Maitreyawira di Batam dan dianggap sebagai pengguna layanan baru di sekolah tersebut. Analisis data dilakukan dalam beberapa tahapan seperti uji $F$, uji t, dan analisis regresi linier berganda. Hasil penelitian ini menunjukkan bahwa WOM (promosi yang dilakukan dari mulut ke mulut) memiliki pengaruh terhadap keputusan untuk memilih Kelompok Bermain/Taman Kanak-kanak Maitreyawira. Sementara e-WOM (promosi dari mulut ke mulut melalui media elektronik) tidak mempengaruhi keputusan untuk memilih Kelompok Bermain/Tamana Kanak-kanak Maitreyawira.
\end{abstract}

Kata kunci: e-WOM; keputusan pemilihan sekolah; WOM.

\title{
INTRODUCTION
}

Marketing activities are one of the principal activities in improving a business and efforts to maintain the survival of the business, to develop and gain the maximum profit. The success or failure in achieving business objectives depends on the expertise of individuals in mastering marketing, production, finance skills (Putra, 2011). To attract consumers to choose the product/service, the company should be able to implement a proper marketing strategy based on the market conditions faced at that time. Therefore, this study interested in researching the analysis of marketing changes occurring in education institutions. Maitreyawira Playgroup/Kindergarten school is the institution has been running for about 10 years that has experienced a massive marketing change from conventional/traditional marketing to digital marketing/online marketing. The digital marketing reflected the transformation of direct selling based on Word of Mouth (WoM) to e-WOM (electronic Word-of-Mouth).

Today, the world faces a new era of globalization in which more countries implement liberalization as well as economic reforms that supported by the development of communication technology and transportation. The world of marketing begins to follow the changes that tend to make frequent use of Internet in worldwide communication. Entrepreneurs become accustomed to the terms Facebook, blog, Web 2.0, social networking, and mobile-based marketing. The rapid technology and communication changes need a new approach, because if marketing management still maintain the traditional marketing model, the business will not be able to catching up with the sophisticated development of Internet Technology (IT). 
The development of information and communication technology have changed the marketing strategy patterns. Since the beginning of 2000, information technology has become a tool to escalate market penetration which continues to evolve into New Wave Technology. New Wave Technology is a technology that enables connectivity and interaction by individuals and groups (Kartajaya, 2013). Because social media costs are cheap and free, the media will be the future for marketing communication. Social media can be interpreted as an application, platform and online media that aim to facilitate interaction, collaboration and sharing of content (Richter \& Koch, 2007). Social media has various forms namely: weblogs, social blogs, microblogging, Wikipedia, podcasts, images, videos, ratings, and social bookmarks. The increasing use of social media exponentially, not only enlarging the business network of company and government organizations but also used empowered the company activities as a communication tool. Unlike individual social networks, companies actively use media for advertising and marketing. Through this social media, the company could enhance the message and commercial interaction with consumers and marketing activities can be integrated with more effective effort and efficient cost.

According to Kim and Ko (2010), the social media has a dramatic impact to brand reputation. One third of survey participants in their study stated opinions about products and brands on brand blogs, and 36\% thought more positively about companies that have blogs. A recent study by DEI Worldwide (2008) provides the following statistics: $70 \%$ of consumers have visited social media sites to get information; $49 \%$ of these consumers have made purchasing decisions based on information they found through social media sites; $60 \%$ of these consumers tend to use social media sites to convey information to others online; and $45 \%$ of those who search for information through social media sites that flow through the mouth of the mouth. The results of the report stated that companies were not involved in social media as the part of their online marketing strategy, might lost their opportunity to gain more consumers. Furthermore, this statement is reinforced by research conducted by Kim and Ko (2012) that found about some activities of social media marketing that have a positive influence on some equity, namely value equity, relationship equity, and brand equity as well as its impact on purchase intentions.

One of interesting object of research is education institution, especially in the level of playgroup/kindergarted (pre-school) Maitreyawira in Batam, where the institution operates within a period of approximately ten years. playgroup/kindergarten Maitreyawira in Batam has good products/services that must be offered to the community so that people who interested in education research with the new research approach about moral principles and integrated models (Supar, 2014).

The previous studies revealed that there is insignificant relationship of eWoM to the customer decision to visit tourism place in Bandung (Mawardi, 
Yulianto, \& Suwarduki, 2016). Furthermore, Benkenstein \& Reimer (2018) showed significant relationship of consumer confidence variables to e-WoM marketing. Therefore, this study focuses on the role of marketing function using WoM or eWoM in the field of education.

\section{Promotion Mix}

The promotional mix is a set of promotional elements used to achieve the company's objectives by introducing the product and influencing consumer to buy it (Rahim, 2017). The promotional mix consists of five elements: (Kotler \& Armstrong, 2016).

\section{Advertising}

According to Kotler \& Keller (2016), advertising is a non-personal form of paid communication about the promotion of companies, products and services by a designated sponsor. Advertising involves the use of mass media such as TV, radio, newspapers, magazines, billboards, banners, banners, and slides which have no direct response/response as generated by personal selling (Khanfar, 2016).

\section{Sales Promotion}

According to (Kotler \& Keller, 2016), sales promotion is a form of promotion by providing various types of short-term incentives to influence a person to try or buy a product or service. Sales promotion tools consist of samples, coupons, cash refunds, premiums, price packs, special advertising items, door-prize, awards and promotion point purchases (Kotler \& Armstrong, 2016).

\section{Personal Selling}

Personal selling is a direct interaction with potential customers by explaining, answering questions, and accepting orders (Kotler \& Keller, 2016).There are a few steps that a marketer usually does when making a sale, i.e. (1) identifying qualified consumers, (2) pre-approach, i.e. learning things related to the company and consumers (3) approach, i.e. when marketers meet with consumers, (4) presentations and demonstrations, (5) addressing consumer issues regarding purchases, and (6) follow-up, i.e. ensure consumer satisfaction and repurchase (Kotler \& Armstrong, 2016).

\section{Direct Marketing}

Direct marketing is a direct relationship of company with the consumers who are carefully targeted to get a response and company able to build a relationship with the consumer (Kotler \& Armstrong, 2016). There are six forms of direct marketing such as direct mail, mail order, direct response, direct selling, telemarketing, and digital marketing (Andreansyah, 2014). 
Public Relation

Public relation is defined as the program promotes and protects the company's image and its products (Kotler \& Keller, 2016). The company not only relates to consumers and resellers, but the company needs to relate to broader public interests. The benefit of public relation in marketing is to build the image of the company, support other communication activities, solve the problem, strengthen the positioning of the company, affect the public, and launch new products/services (Andreansyah, 2014).

\section{Word of Mouth (WoM)}

Word of Mouth (WoM) is one of the most important factors in the business as a word of mouth communication (Payne, 2007). Therefore, it can be concluded that WoM is a communication in the form of speech or testimonial stated by customers who share about the products they have ever tried to others. Trusov, Bucklin, and Pauwels (2009) stated that WoM recently attracted a lot of attention among practitioners. Some literatures mentioned about WOM as a viable alternative to be used as a traditional marketing communication tool. Furthermore, Cheung and Thadani (2012) intensively conducted a systematic review of several studies on eWoM. Based on the analysis of their literature, they used a social communication framework to summarize and classify previous e-WoM studies. Furthermore, Cheung and Thadani (2012) identified the key factors related to the main elements of social communication literature and built an integrative framework that explains the impact of e-WoM communication on consumer behaviour.

The marketing activity revolves around Word of Mouth which no longer applied only on advertising. Many new marketers realize that making their customers selling company products is the best way to increase sales itself. It is the magnitude of people who talk about them to the right people. The consumer community is the best marketing channel because the community members are the direct users who can influence each other and recommend to others (Joko, 2007). The consumer community can be a marketing community who favoured on certain products, such as Bike toWork and there is also a community formed based on the brand.

In addition to the word-of-mouth sales, WoM has evolved into eletronic World of Mouth (e-WoM). E-WoM is defined as a communication medium to share information about a product or service that has been consumed among consumers who are not acquainted with each other and have not met before (Gruen, Osmonbekov, \& Czaplewski, 2006).

\section{Brand Trust}

Trust is perceptions of reliability from a consumer's perspective that based on experience, or more on transaction sequences or interactions characterized by meeting expectations for product performance and satisfaction (Jasfar, 2002). In 
this study, the brand trust is a sense of trust arising from the customer, which will make the reason why they believe in the product. Brand trust transcends consumer satisfaction with the functional performance of the product and its attributes (Aaker, 1996).

Based on the statement above, the brand trust is defined as the following average consumer willingness to rely on the brand's ability to perform the functions it has (Ha \& Perks, 2005). In the online environment, development and maintenance of consumer confidence brands on the web is important, especially in the face of a very unexpected market with differentiation reducing products (Fournier \& Yao, 1997). The issues surrounding privacy and security, related to the main dimensions of the E-brand, influence the online audiences become skeptical to e-commerce or website marketing, especially to the unknown sites. To meet these challenges, web branding should add another dimension of familiarity and security when company build the brand trust (Ha \& Perks, 2005). Familiarity with the company or brand produces a greater sense of trust. Therefore, the reseller relationship of Web customers, based on brand experience, may have a positive effect on the brand trust level.

\section{Product/Service Quality}

Product/service quality is the ability of a product/service in demonstrating its function, which is included in the overall durability, reliability, accuracy, ease of operation and repair of products and other product attributes (Kotler \& Keller, 2016). The consumers are very critical in selecting a product decision to buy a product strongly influenced by the valuation of service quality (Yasa, Rahyuda, \& Suandana, 2014).

In addition, the products as something that can be offered into the market to be considered, owned, worn, or consumed to satisfy the wishes or needs. Quality as the quality of the attributes or properties as described from within the products and services concerned. Individuals assess the quality of consumers' perceived products when consume the products. Quality refers to everything that determines customer satisfaction. A qualified new product determined by the customer's wishes that can be utilized properly and manufactured in a good and correct way.

The good and service quality usually related to the benefits or usefulness and functionality of a product. Quality also becomes a factor that contained in a product that causes the product to be worthed based on the purpose for which the product was produced. Quality is determined by a set of uses or its function, including its durability, reliance on other products or components, exclusive, comfort, outer form such as color, shape, packaging, etc (Tjiptono, 2008).

If the marketers concerned about the quality, increase advertising effort and implement reasonable product prices, consumer will not think twice to make a purchase against the product. This statement concerns about the consumer ratings 
of imagery, branding or advertising. Branded product is usually in a more highquality prevalence in appeals with brands that rarely heard. In addition, the product can be defined as consumer perception that described by ten producers through production results. The more detail expression about the concept of total products including goods, packaging, brands, labels, services, and guarantees (Tjiptono, 2008).

Quality also has an important role either in the perspective of consumers who freely choose the level of quality or in the perspective of manufacturers who begin to pay attention to control quality in order to maintain service quality. To achieve the desired service quality, the quality standardization is required. This is intended to allow to meet predefined standards of products so that consumers will not lose confidence in the product.

\section{The Selection Decision}

Purchasing decision is a process in a problem solving approach that consists of introduction of problems, information retrieval, some alternative assessments, making a decision to choose, and consumer behavior after purchasing (Kotler \& Keller, 2016). It concludes that there are several types of behaviors in selection decisions, which every consumer behavior is influenced by habits, product brands, situations or time, and the number of alternatives available. The selection behavior for food product types tends to lead to the third type of behavior that is buying because of habits, but it can also include the type of buying behavior that seeks diversity or product variation. In this study, the purchase decision was changed to selection decision.

There are five stages that consumers go through to take a purchase decision, namely (Kotler, 2005).

\section{Problem Identification}

The purchase process will begin when the consumer recognizes a problem or need that triggered by internal or external stimulant.

\section{Searching Information}

Consumers who already know their needs will be encouraged to seek more information. There are two levels of encouragement. A lighter information search situation called attention strengthening. In the first level, people are only sensitive to product information. On the second level, consumers may be actively entering information search such as search for reading materials, calling friends, and visiting stores to learn which products you've searched for.

\section{Alternative Evaluation}

The market should be aware of alternative evaluation that involves how a consumer can process competitive brand information on the market and make final judgments. There is no simple single evaluation process used by all consumers or 
by one consumer in a purchase situation. How consumers evaluate alternatives depends on personal consumers and specific purchasing situations.

\section{Purchase Decision}

In this stage, consumers form preferences of the brands within the set of options. The consumer is also able to form the intention to purchase the most favorite brand of products. However, two factors influence the purchase intention or purchase decision. The first factor is the attitude of others, the extent to which the attitude of others can reduce the alternatives someone has liked. The second factor is an unanticipated situation factor that can arise and change the consumer's buying intention. In this study, the purchase decision was changed to the selection decision.

\section{Post-Selection Behaviour}

After purchasing the product, the consumer will experience a level of satisfaction or dissatisfaction with the product. The seller's job not only ends when the product is purchased by consumers. Marketers should monitor post-purchase satisfaction, post-election action, and use post-election products.

Marketers should monitor their post-election satisfaction, post-election action and post-election product usage. If the product performance is lower than expectations, the customer will be disappointed with the product, if the product turns out according to expectations, the customer will be satisfied with the product, if the product exceeds expectations, the customer will be very satisfied with the product.

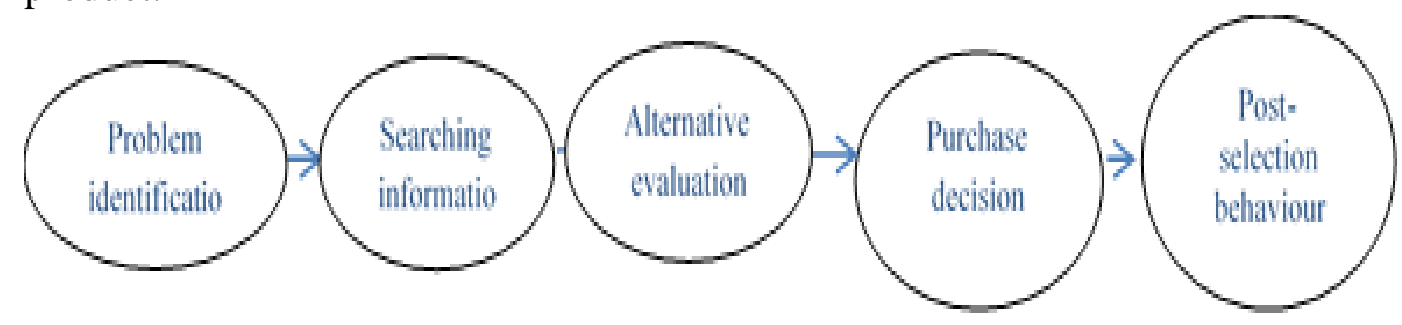

Figure1. The Stage of Purchase Decision

The Model on Figure 1 shows that the consumers must go through all five stages of the sequence when buying a product, but not always. The stage of purchase decision is most rely on the basic nature of buyers, products, and election situations.

New products are goods, services or ideas that are considered new by several potential customers (Kotler \& Keller, 2008). The adoption process is defined as a mental process that one must pass through in order to learn an innovation for the first time until final adoption, and adoption is a person's decision to become a user of a fixed product. 
Therefore, the hypotheses of this study are:

H1: There is a positive and significant influence of WoM, service quality and brand trust to the decision of parents' school selection.

$\mathrm{H} 2$ : There is a positive and significant influence of e-WOM, service quality and brand trust to the decision of parent's school selection.

\section{METHODS}

This research uses a quantitative approach that emphasizes the measurement and sampling methods because it uses a deductive approach that stresses detailed priorities on data collection and analysis (Hair, Ortinau, \& Bush, 2006). Based on the purpose, this research is exploratory so that the research aims to explain the influence of WoM, service quality, brand trust toward the decision of parents choose the playgroup/kindergarten Maitreyawira in Batam. According to the reliability test of questionnaire 1 that investigated the influence of WoM, service quality, brand trust and parents' school selection have high reliability with Cronbach Alpha about 0.878. Meanwhile, the reliability test of questionnaire 2 shows that WoM, service quality, brand trust, and parent's school selection have a high-reliability value with Cronbach Alpha about 0.799. It reflects that both questionnaire types have high stability level, consistency, predictive ability, and accuracy.

The research site is located at playgroup/kindergarten Maitreyawira. Komplek Maha Vihara Duta Maitreya, Sungai Panas, Batam City, Indonesia. The study conducted from June 2018 to June 2019.

The research population is the parents whose children study in the playgroup/kindergarten Maitreyawira in Batam. The sampling technique used is purposive/judgmental sampling which gathered information from parents who recognized as the new service user of school.

The data used in this research is primary data, which is gathered from the questionnaire from parents as respondents to the study. The data collection method used in this research is giving questionnaires. This technique gives respondents the responsibility to read and answer questions, which researchers can explain the purpose of surveys and questions that able understood by respondents and responses to questionnaires. Therefore, an efficient collection of data able to know exactly what is needed and how to measure the research variables.

The data analysis methods are descriptive statistical analysis and inferential statistical analysis. This descriptive analysis is performed through descriptive hypothesis testing. This method is commonly used by researchers for information on the number and percentage of respondents' demographic characteristics (Harris, 2017). 
BISMA (Bisnis dan Manajemen)

Volume 12 Issue 1, October 2019

E-ISSN 2549-7790, P-ISSN 1979-7192

Page 54-65

\section{RESULT AND DISCUSSION}

\section{Result}

Figure 2 reflects the research model that tested in the study. The F Test is conducted in the research model 1 and 2 to predict the decision of the school selection, which means that the three variables affect the school selection decisions simultaneously.
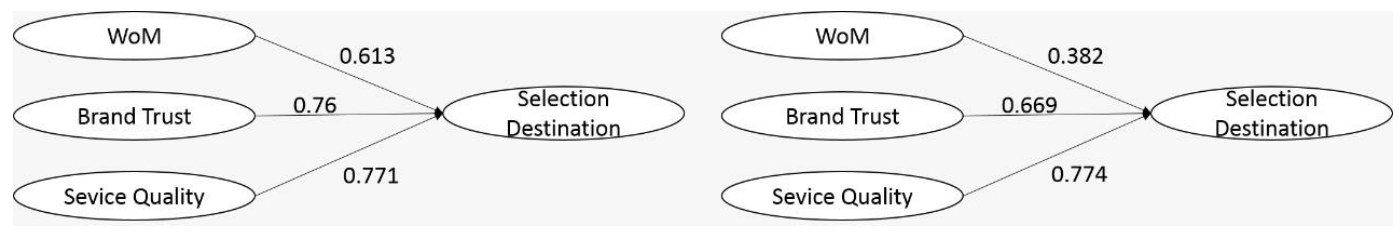

Figure 2 The Correlation Coefficient Result of Research Variables

The research model 1 tests the influence of WoM, brand trust, and service quality on the school selection. Meanwhile, the research model 2 tests the influence of e-WOM, brand trust, and service quality on the school selection. Based on the multiple regression calculation of model 1 , WoM, brand trust, and service quality are simultaneously influenced by parent's school selection about $61.3 \%$ (WOM), $76 \%$ (brand trust), and $77 \%$ (service quality) respectively or $\mathrm{H} 1$ is accepted. Furthermore, the multiple regression calculation of model 2 shows e-WoM did not influence the parents' school selection $(38.2 \%)$, while the brand trust $(66.9 \%)$ and service quality $(77.4 \%)$ shows positive and significant correlation on parents' school selection or $\mathrm{H} 2$ is declined.

\section{Discussion}

The result implies that there are multiple reasons for parents when choosing a school for their students. In this study, WoM, service quality, and brand trust are proven to influence the parent's decision to choose their children's school. Nevertheless, e-WoM as the latest form of WoM has not a positive and significant influence on school selection although combined with service quality and brand trust. Furthermore, it indicates that partially, WoM is the weakest variable that influences parents to choose the school that fits their needs and expectation. Therefore, WoM and e-WoM can't be tested partially to know its influence on parent's school selection. Furthermore, brand trust and service quality are positively and significantly influence the parent's school selection. This result supports the previous research about the positive influence of service quality and brand trust on customer behavioral intention (Choudhury, 2015) and rejects the positive influence of e-WoM on customer behavioral intention (Gretzel et al. 2016). 


\section{CONCLUSION}

It can be concluded that WoM has a significant effect on school selection decisions and e-WoM is insignificant to the decision of the school selection. Furthermore, WoM, brand trust, and service quality have a significant effect on school selection decisions. Conversely, e-WoM has no significant effect on the decision of the school selection, while the level of trust and service quality has a significant effect on the decision of school selection in Batam. A major limitation of this research is the respondents do not have adequate knowledge about the difference of WoM and E-WoM. Furthermore, further research needs to be developed by explaining more detailed information in the questionnaire form to avoid the respondent's bias and enhance the ability of respondents to answer the questionnaire.

\section{REFERENCES}

Aaker, D. (1996). Building Strong Brands. New York: The Free Press.

Andreansyah, R. B. (2014). Pengaruh Strategi Promosi terhadap Keputusan Berkunjung Wisatawan Mancanegara. Jurnal Ilmu \& Riset Manajemen, 3(6), $1-17$.

Benkenstein, M., \& Reimer, T. (2018). Not just for the recommender: How e-WoM incentives influence the recommendation audience. Journal of Business Research, 11-21.

Cheung, C.M.K., and Thadani, D. R., (2012). The impact of electronic word- of mouth communication: A literature analysis and integrative model. DecisionSupport Systems, 54: 461-470

Choudhury, K. (2015), "Service quality and customers' behavioural intentions", Asia Pacific Journal of Marketing and Logistics, Vol. 27 No. 5, pp. 735-757. https://doi.org/10.1108/APJML-02-2015-0025

DEI Worldwide. (2008). The impact of social media on purchasing behavior. Engaging Consumers Online. Available at www.deiworldwide.com/files/DEIStudy-Engaging\% 20 Consumer OlineSummary.pdf

Fournier, S., \& Yao, J. (1997). Reviving Brand Loyalty: A Reconceptualization within the Framework of Consumer-Brand Relationships. International Journal of Research in Marketing, 451.

Gretzel, Lina Zhong and Chulmo Koo, U., Doosti, S., Jalilvand, M., Asadi, A., Khazaei Pool, J. and Mehrani Adl, P. (2016), "Analyzing the influence of electronic word of mouth on visit intention: the mediating role of tourists' attitude and city image", International Journal of Tourism Cities, Vol. 2 No. 2, pp. 137-148. https://doi.org/10.1108/IJTC-12-2015-0031 
BISMA (Bisnis dan Manajemen)

Volume 12 Issue 1, October 2019

E-ISSN 2549-7790, P-ISSN 1979-7192

Page 54-65

Gruen, T. W., Osmonbekov, T., \& Czaplewski, A. J. (2006). e-WOM: the impact of customer to customer online know how exchange on customere value and loyalty. Journal of business research, 449-456.

Ha, H. Y., \& Perks, H. (2005). Pengaruh Persepsi Konsumen Pengalaman Merek Di Web: Keakraban Brand Kepuasan, dan Kepercayaan Merek. Journal Cosumer Behavior, 442-443.

Hair, J. F., Ortinau, \& Bush. (2006). Multivariate Data Analysis. Jakarta: Gramedia Pustaka Utama.

Harris, I. (2017). Analisis Technology Acceptance Model (TAM) Terhadap Tingkat Penerimaan E-Learning Pada Kalangan Mahasiswa (Studi Empiris pada Universitas Internasional Batam dan UPBJJ-UT Batam). Jurnal Terapan Manajemen dan Bisnis, 3(1).

Indrianto, Nur, \& Supomo. (2014). Metodologi Penelitian Bisnis untuk Akuntansi dan Manajemen. Yogyakarta: BPFE.

Jasfar, F. (2002). Perbedaan Peranan Tingkat Kepuasan. Akuntansi, 9.

Joko, S. (2007). Seni Membidani dan Mengendarai Komunitas. Jurnal Pengetahuan, 4.

Khanfar, I. A. (2016). The Effect of Promotion Mix Elements on Consumers Buying Decisions of Mobile Service: The Case of Umniah Telecommunication Company at Zarqa City - Jordan. European Journal of Business and Management, 8(5), 94-100.

Kim, AJ., and Ko, E (2012) Do social media marketing activities enhance customer equity? An empirical study of luxury brand. Journal of Business Research, 65: $1480-1486$

Kim AJ, and Ko E. (2010). Impacts of luxury fashion brand's social media marketing on customer relationship and purchase intention. J Glob Fashion Mark;1(3):164-71

Kartajaya, H. (2013). Tourism Marketing 3.0. Jakarta: PT. Gramedia Pustaka Utama.

Kotler, \& Armstrong, G. (2016). Prinsip - Prinsip Pemasaran. Eidisi 12 Jilid 2, PenerbitErlangga. https://doi.org/10.2307/1250103.

Kotler, P. (2005). Manajamen Pemasaran. Jakarta: PT. Indeks Kelompok Gramedia.

Kotler, P., \& Keller, K. L. (2016). Marketing Management. Global Edition. https://doi.org/10.1080/08911760903022556. 
Mawardi, M. K., Yulianto, E., \& Suwarduki, R. P. (2016). Pengaruh Electronic Wolrd OfMouth Terhadap Citra Destinasi Serta Dampaknya Pada Minat Dan Keputusan Berkunjung. Jurnal Admintrasi Bisnis, 8.

Payne, A. (2007). The Essence of Service Marketing (Pemasaran Jasa). Pemasaran Jasa, 72.

Putra, F. H. (2011). Analisis Pengaruh Strategi Pemasaran Produk dan Harga Terhadap Volume Penjualan Nikel Pada PT.Antam Tbk. Strategi Pemasaran, $1-3$.

Rahim, R. (2017). PengaruhBauranPromositerhadap Keputusan WisatawanuntukBerkunjungkeDaya Tarik WisataLadayaKutaiKartanegara. Journal AdministrasiBisnis, 5(1), 13-25.

Richter A, Koch M. (2007).Social software - status quo und Zukunft.TechnischerBericht, Nr., FakultätfürInformatik. Universität der Bundeswehr München

Supar. (2014). Strategi Pemasaran Sekolah Dasar Islam Terpadu. Jurnal Humanity, 158.

Tjiptono, F. (2008). Total Quality Management. Yogyakarta: Andi.

Trusov, M., Bucklin, R.E., and Pauwels, K. (2009). Effects of word-of-mouth versus traditional marketing: Findings from an internet social netword site. Journal of Marketing, Vol. 73: 90--102. 